\title{
Effective State in the System of New Socio-economic Formation
}

\author{
Vadim O. Evseev, Tatiana V. Skryl* \\ Department of Political Science and Sociology, Department \\ of Economic Theory \\ Plekhanov Russian University of Economics \\ Moscow, Russia \\ t_skryl@mail.ru
}

\author{
Vladimir S. Osipov \\ Department of Risk Management and Insurance \\ MGIMO University, \\ Institute of Market Problems \\ Russian Academy of Science \\ Moscow, Russia \\ vs.ossipov@gmail.com
}

\begin{abstract}
The main goal of this paper is to confirm that there is a new socio-economic formation with sustainable development characteristics (on example of Russia). The method of system analysis and modeling was chosen as a research method. A new system of indicators for assessing the effectiveness of public administration is proposed. Based on the semantic model, the characteristics of the USSR, the current Russia and the model of the new Russia, which is developing in the new socio-economic formation, were studied. A table with the numerical characteristics of the three stages of development of Russia is given. In conclusion, it is concluded that Russia as an effective state can be built only in the new socio-economic formation.
\end{abstract}

Keywords-Social formation; Instituion; Self-government; Sustainable development; Effective state; Russia; Public administration

\section{INTRODUCTION}

To achieve an effective state is possible only as a result of a new transformation of socio-economic relations, which have always been associated with the redistribution of forms of ownership. According to the goal, we consider the main system characteristics of the state (on example of Russia) to confirm that effective state could be built only in basis of development and strengthening of the national control function.

From the standpoint of system analysis, the law of evolutionary and positive development of complex systems, including socio-economic systems, is the transformation of the system to minimize its internal contradictions. If we take for $100 \%$ the level of social contradictions in the feudalism, in the capitalism, the level of social contradictions is already $60 \%$, in socialism, the level of social and social contradictions is $35 \%[1]$. In the next new social formation or a new state system, the level of social contradictions should be even less. Therefore, the analysis of historical events from the standpoint of system analysis, it can be said that the Revolution of 1917 resolved the main social system contradiction - the antagonistic contradiction between labor and capital, and in the USSR socially significant contradictions were less than in Tsarist Russia[1]. The collapse of the Soviet Union returned the population, despite the Declaration on the social state, to the initial stage of development of capitalist society, only more or less on a perfect information and technological basis, which, as practice has shown, made it possible to make the transition to capitalist values even faster.

It should be noted that in capitalist countries the methodological apparatus of competition in the socio-economic and socio-political spheres was better developed and tested, because they "punched" political, economic, legal, ethical and other barriers that prevented them from capturing the economic and natural assets of foreign countries [2]. The USSR was also one of such countries, which in the socio-political sphere could not oppose their methods of struggle to their methods, and therefore ceased to exist in the former formation[3].

Despite of the fact that the country collapsed, but the idea of building a state with minimal internal social contradictions remained, because this idea of systemic sustainable development. Entering into market relations, Russia quickly enough (quickly by historical standards) realized the methods and techniques (legitimate and not legitimate) of competition in the market of capitalist relations - is on the one hand. On the other hand, according to the convergence theory, it has already "slammed" capitalist ideology, especially in its superstructure base. In Russia, the same antagonistic contradictions between "labor and capital", which were overthrown by the Revolution of 1917 , began to be fully manifested.

\section{MATERIALS AND METHODS}

Based on the method of system analysis, the theory of development of complex systems[4,5,6], the method of modeling, a model of a new socio-economic formation was built (the model was based on statistical information on Russia and the world). The model includes more than 1000 equations, including the equations of budget distribution and demographic growth[7] One of the criteria for the effectiveness of the development of the new socio-economic formation was the indicator of the competitiveness of the country and the HDI. Because of multivariate calculations, the parameters of the new socio-economic formation were obtained, in which $66 \%$ of the fixed assets belong to the people, $12 \%$ of fixed assets belongs to the state, $22 \%$ of fixed assets belongs to the private sector. The model showed sustainable development of the social sphere and demographic processes[8]. In the model, the antagonistic contradictions of "labor and capital" were solved. The society in the model is transferred to the principles of selfgovernment and self-financing. 
The model confirms the age-old thesis about the right to power and the right to property: who owns the main production funds and financial flows in the country - that the prospect of sustainable development. Therefore, the further sustainable and competitive development of Russia is again connected only with the redistribution of fixed assets[9]. The privatization policy of the Russian Government is also destructive from the standpoint of the theory of development of complex systems. The existing policy contributes to the emergence and consolidation of centers of controlled chaos in the socioeconomic environment, which is fueled by the growing social and economic contradictions. Before the election of the President in 2018, in his election program, the forces of public opinion of the Russian electorate should focus on the transition to a model of a new socio-economic formation, where $66 \%$ of the fixed assets belong to the people of Russia, only such a redistribution of fixed assets will make Russia an effective state[10].

It should be noted that in the XX and XXI centuries there were new scientific disciplines with a new conceptual apparatus that allow you to better see the retrospective of historical events and better formalize the concept of "effective state"[11]. To build an effective state is possible only in the context of transformation of the socio - political system. Only in the context of understanding of the global laws of development: division and cooperation of labor; antagonistic contradictions between labor and capital; the law of necessary additions; the law of the ratio of reasonable and limit; the law of self-organization of complex systems on the principle of minimizing internal contradictions; the law of interconnection resolution of internal contradictions and the presence of effective feedback; etc.

\section{RESULTS AND DISCUSSION}

The following is an example of modeling the characteristics of an effective state (see Table I). The proposed model considers and studies a complex self-organizing system - the state and the dynamics of its development in the form of formations: socialist, capitalist and new-system[12]. The criterion of effective development of the state was chosen system of indicators characteristic of the analysis of complex systems, characterizing its state and directly reflecting the level of sustainable development.

To study the effectiveness of the state at various stages of its development and obtain system quantitative characteristics about it, the model was introduced expert semantic information corresponding to various social formations. The results of the model (see Table I) confirmed the validity of the creation of a new system state of a democratic type, whose activities and characteristics are not only consistent with the goals and objectives of the society and the state, but also protect these interests within the country and in the international arena. of:

The results obtained by the model confirmed the possibility

1) Quantitative and systematic description of the characteristics of the state in the indicators typical for complex systems;
2) Building an effective state, with the strengthening of its democratic foundations;

3) Creation of a new scientific-based socio-economic formation;

4) Availability of the main system directions for the modernization of the current model of the state.

The system state of the $21 \mathrm{st}$ century with new characteristics is a competitive geopolitical product in the international market of social and political ideas[13] [14]. The new socio - economic formation meets the interests of society in any state of the world where they are looking for new ways of development, and meets and solves the eternal question: "society - development - capital — democracy - selfgovernment", only in the new formation can create a truly effective state[15].

TABLE I. SYSTEM CHARACTERISTICS OF THE FUNCTIONING OF THE STATE

\begin{tabular}{|c|c|c|c|c|}
\hline & $\begin{array}{c}\text { Systems } \\
\text { Characteristics }\end{array}$ & USSR & $\begin{array}{c}\text { Russia } \\
\text { (current) }\end{array}$ & $\begin{array}{c}\text { Russia } \\
\text { (new } \\
\text { formation) }\end{array}$ \\
\hline 1. & \multicolumn{4}{|c|}{ Focus on Society, \% } \\
\hline 1.1. & Level of declarative & 55.6 & 44.4 & 41.7 \\
\hline 1.2. & $\begin{array}{l}\text { Level of reliance on } \\
\text { the potential of } \\
\text { society, }\end{array}$ & 44.4 & 58.3 & 55.6 \\
\hline 1.3 . & $\begin{array}{l}\text { Level of reliance on } \\
\text { the potential of the } \\
\text { state system, }\end{array}$ & 81.8 & 50.0 & 84.1 \\
\hline 1.4. & $\begin{array}{l}\text { Level of } \\
\text { tension }\end{array}$ & 63.6 & 84.1 & 52.3 \\
\hline 1.5 . & $\begin{array}{l}\text { Type of leadership } \\
\text { of society, }\end{array}$ & Authoritarian & Liberal, & Democratic \\
\hline 2. & \multicolumn{4}{|c|}{ Focus on Tasks, \% } \\
\hline 2.1. & Level of declarative & 22.4 & 56.6 & 14.5 \\
\hline 2.2 & $\begin{array}{ll}\begin{array}{l}\text { Level } \\
\text { sophistication }\end{array} & \text { of } \\
\end{array}$ & 66.1 & 9.1 & 64.6 \\
\hline 2.3 . & $\begin{array}{l}\text { Level of training of } \\
\text { the task }\end{array}$ & $\begin{array}{l}\text { Technical } \\
\text { task }\end{array}$ & $\begin{array}{l}\text { General } \\
\text { ideas }\end{array}$ & $\begin{array}{l}\text { Technical } \\
\text { task }\end{array}$ \\
\hline 3. & \multicolumn{4}{|c|}{ Focus on the Business, \% } \\
\hline 3.1. & Level of declarative & 15.5 & 58.8 & 13.8 \\
\hline 3.2. & $\begin{array}{l}\text { Level of business } \\
\text { focus }\end{array}$ & 81.7 & 21.2 & 78.3 \\
\hline 3.3 . & Business mindset & $\begin{array}{l}\text { Upper- } \\
\text { middle }\end{array}$ & Low & High \\
\hline 4. & \multicolumn{4}{|c|}{ Coefficients of the system state, \% } \\
\hline 4.1. & $\begin{array}{lr}\text { Coefficient } & \text { of } \\
\text { preparedness } & \text { for } \\
\text { failure } & \\
\end{array}$ & 62 & 47 & 69 \\
\hline 4.2. & $\begin{array}{l}\text { Coefficient of } \\
\text { internal } \\
\text { coordination }\end{array}$ & 63 & 13 & 70 \\
\hline 4.3. & $\begin{array}{l}\text { Coefficient } \\
\text { management } \\
\text { coordination }\end{array}$ & 75 & 48 & 89 \\
\hline 4.4. & $\begin{array}{l}\text { Coefficient } \\
\text { organizational } \\
\text { readiness }\end{array}$ & 74 & 11 & 71 \\
\hline 4.5 . & $\begin{array}{l}\text { Coefficient of } \\
\begin{array}{l}\text { control of the } \\
\text { situation }\end{array}\end{array}$ & 61 & 33 & 88 \\
\hline 4.6. & $\begin{array}{lr}\text { Coefficient } & \text { of } \\
\text { readiness } & \text { for } \\
\text { changes } & \\
\end{array}$ & 26 & 18 & 54 \\
\hline
\end{tabular}




\section{Authors' calculations based on Federal Statistic Data[16]}

The values of the obtained characteristics for all forms of government[17]: the USSR, modern Russia[18], the model of state structure in the new Russia, were analyzed on the close relationship between them[19]. The obtained correlation coefficients, the range of which was within the limits of 0,79 0,85-0 95, confirmed the presence of close dependence. The correlations confirmed the internal consistency, the consistency of the dialectical nature of the developed model. The analysis of the mentioned characteristics revealed interesting dependencies:

1) If we consider the impact of the characteristics of situation control on other system characteristics: the characteristics of social tension and declarative - decrease; characteristics of internal coordination and preparedness for failures - increase. The optimal level of control of the situation in society can be considered the range from $75 \%$ to $85 \%$, control over $85 \%$ can reduce the level of internal unity of society.

2) If we consider the impact of characteristics of the part system for other system characteristics, for example: the characteristics of openness to change and preparedness to failure, which increases. Willingness to societal changes affected the capacity of the state system is a very significant relationship. It suggests that while the society is not connected more than $80 \%$ of capacity in the public system, there is no need to speak about any changes.

\section{CONCLUSION}

The state system, which cannot make its state-owned enterprises efficient and competitive, has no prospects for development. Until a new generation of system state mechanism based on scientifically grounded redistribution of fixed production assets is created, it is impossible to create a foothold for qualitative changes in the country, for building an effective state on system principles. The practical implementation has shown that if you fold $66 \%$ of the basic production fixed assets, which are assigned by people, and $12 \%$ of fixed assets that are assigned to the state, you get $78 \%$ (regression model), which is very close to $80 \%$ of the active capacity of the system (the semantic model).

Based on the analysis of three forms of Russian state the authors concluded that effective state could be built in a frame of redistribution of fixed assets and increasing the level of cohesion as the general factors of positive transformation.

\section{REFERENCES}

[1] S.Y. Glazyev, Lessons of the next Russian revolution. The collapse of the liberal utopia and a chance for an"economic miracle, M.: Economic newspaper, 2011, pp.34-40

[2] S.Y. Glazyev, Economics of the future. Does Russia have a chance? M. Book world, 2017, pp.56

[3] V.O. Evseev, Competitiveness in the new socio-economic formation (Economic model of the new vector of development of society), Riga: Palmarium Academic Publishing, 2016, pp.102

[4] J.P. Olsen, Governing through Institution Building: Institutional Theory and Recent European Experiments in Democratic Organization, Oxford: Oxford University Press, 2010, pp.202

[5] C. Johnson, MITI and the Japanese Miracle: The growth of industrial policy, 1925-1975, Stanford, Stanford, 1982, pp.340

[6] G. Myrdal, The Political Element in the Development of Economic Theory, University Press, 1956, pp.45

[7] A.M. Kjær, Governance, Cambridge: Polity Press, 2004, pp.451

[8] M. Castells, "Toward a Sociology of the Network Society," Contemporary Sociology, vol. 29(5), pp.33, 2000

[9] A. Maarten, M.A. Hajer, and H. Wagenaar, Deliberative Policy Analysis Understanding Governance in the Network Society, New York: Cambridge University Press, 2003, pp.110

[10] T. Bovaird, "Public Governance: Balancing Stakeholder Power in a Network Society," International Review of Administrative Sciences, vol. 71(2), pp. 54, 2005.

[11] T.V. Skryl, “A paradigm shift in Russia's industrial policy: From a raw model to innovative technological growth points," International Journal of Ecological Economics and Statistics, vol. 38(2), pp. 49-58, 2017.

[12] R.M. Solow, "Technical Change and the Aggregate Production Function," Review of Economics and Statistics (The MIT Press), vol. 39 (3), pp. 312-320, 1957.

[13] J. Schumpeter, Business Cycles: A Theoretical, Historical and Statistical Analysis, New York; London: McGraw-Hill Book Company Inc., 1964, pp.44-47

[14] J. Schumpeter, The Theory of Economic Development: An Inquiry into Profits, Capital, Credit, Interest and Business Cycle, New York: Oxford University Press, 1969, pp.205

[15] V.S. Osipov, "Capitalist structure of the Russian economy: institutional approach," Research and development, Economics of the company. INFRA-M, vol.6(3). pp. 61-66, 2017.

[16] Federal Statictic Base [www.gks.ru]

[17] S.E. Sjöstrand, On Economic Institutions. Theory and Applications, Aldershot: Edward Elgar, 1995, pp.78

[18] E. Reinert, J. Ghosh, and R. Kattel, The Elgar Companion to Alternative Theories of Economic Development Cheltenham: Elgar, 2016, pp.169

[19] T.V. Skryl, V.S. Osipov, and V.O. Evseev, "The interaction model of business and state as a factor in human resource management," Source: Proceedings of the Second International Conference on Economic and Business Management (Febm 2017) vol. 33, pp. 862-868. 